\title{
Comment on 'Evidence for an Early-Middle Miocene age of the Navidad Formation (central Chile): Paleontological, paleoclimatic and tectonic implications' of Gutiérrez et al. (2013, Andean Geology 40 (1): 66-78)
}

\author{
Kenneth L. Finger ${ }^{1}$, Alfonso Encinas ${ }^{2}$, Sven N. Nielsen ${ }^{3}$
}

\author{
Iniversity of California Museum of Paleontology, 1101 Valley Life Sciences Building, Berkeley, CA 94720-4780, USA. \\ kfinger@berkeley.edu \\ 2 Departamento de Ciencias de la Tierra, Universidad de Concepción, Casilla 160-C, Concepción, Chile. \\ aencinas@udec.cl \\ 3 Instituto de Ciencias Ambientales y Evolutivas, Universidad Austral de Chile, Casilla 567, Valdivia, Chile. \\ sven.nielsen@uach.cl
}

The Navidad Formation has been the reference unit for the marine Neogene of Chile and the debate about its age and depositional paleoenvironment has a long history. In their recent contribution, Gutiérrez et al. present an interpretation of the Navidad Formation that contrasts with that our research group concluded and incorporated in several publications (Encinas, 2006; Encinas et al., 2006; Finger et al., 2007; Encinas et al., 2008; Nielsen and Glodny, 2009). Gutiérrez et al. base their conclusions mostly on our and others' data, adding eight new ${ }^{87} \mathrm{Sr} /{ }^{86} \mathrm{Sr}$ and two new ${ }^{40} \mathrm{Ar} /{ }^{39} \mathrm{Ar}$ age determinations. Most of the arguments presented in their work have been debated by our group for more than a decade, and Finger et al. (2007) expounded upon them. Despite our previous attempt to make sense of the contradictory data, we expected the issues were likely to remain controversial. We therefore welcome further discussion on these subjects.

The crux of discontent is the Late Miocene-Early Pliocene age interval that we proposed on the basis of planktic foraminifers identified in Finger et al. (2007), as molluscan biostratigraphy and strontium isotope stratigraphy indicate that the Navidad is older. Gutiérrez et al. conclude that the five planktic foraminifer index species cited by Finger et al. (2007) must have appeared $\sim 15$ Myr earlier in the Southeast
Pacific than elsewhere in the global ocean. Even though we have revised our conclusions based on further study, we consider that explanation to be implausible. We are confident that we have finally resolved the debate about the age of the Navidad outcrops along the coast of south-central Chile.

A second point of contention has been the depositional environment of the Navidad Formation, which we interpreted as being deep-water (i.e., continental slope) but which Gutiérrez et al. argue to be shallower (i.e., continental shelf). We address this issue as well, and can only hope that it will also be put to rest.

\section{Age of the Navidad Formation}

Gutiérrez et al. claim that the published data overwhelmingly favors an Early to Middle Miocene age. That assessment is misleading because a Late Miocene or younger age for the unit had been interpreted from foraminifers (Martínez-Pardo and Osorio, 1964; Ibaraki, 1992; Finger et al., 2007), ostracodes (Osorio, 1978), pollen (Méon et al., 1994), and one ${ }^{40} \mathrm{Ar} /{ }^{39} \mathrm{Ar}$ age (Encinas, 2006). In addition, one $\mathrm{Sr} / \mathrm{Sr}$ correlated with the latest Middle Miocene (Encinas, 2006). On the other hand, an Early Miocene age was derived from studies on molluscs (DeVries 
and Frassinetti, 2003; Finger et al., 2007), shark teeth (Suárez et al., 2006), Sr isotopes (Encinas, 2006, Nielsen and Glodny, 2009; Gutiérrez et al., 2013), and ${ }^{40} \mathrm{Ar} /{ }^{39} \mathrm{Ar}$ and $\mathrm{K} / \mathrm{Ar}$ dating of volcanics (Encinas, 2006; Gutiérrez et al., 2013). Overall, the ages proposed in publications on the Navidad Formation are equally divided into the intervals before and after the late Middle Miocene global cooling event. Gutiérrez et al. (2013) discuss most of the available data, questioning those that were used in determining the younger age. In the following, we respond to their findings, some of which we agree with, and bring attention to some noteworthy data and arguments that we previously presented but they omitted from their discussion.

\subsection{Molluscan biostratigraphy}

Gutiérrez et al. (2013) note that the molluscan fauna of the Navidad Formation contains eight species that DeVries and Frassinetti (2003) recorded in their work on the Late Oligocene-Early Miocene fauna in Peru, and use that to support their age interpretation. In fact, only seven of those species were indicated by Finger et al. (2007), and the number increased to a mere nine $(4.2 \%)$ of 214 species later tallied from the Navidad Formation by Kiel and Nielsen (2010). Gutiérrez et al. do not recognize that all benthic animals are controlled by bottom facies that can be geographically diachronous or discontinuous. Considering the latitudinal distance between the units studied in Chile and Peru, this interbasinal biostratigraphic correlation of molluscs is dubious.

Although we initially speculated that mollusc assemblages were reworked by massive slumping we stated that there is no sedimentological evidence for it and many of the gastropods (including some with delicate ornamentation) are well preserved, there is no difference between the sediment infilling the shells and that of the surrounding matrix, and there are shallow-water mollusc associations in sandstones and deep-water associations in siltstones (Finger et al., 2007). Gutiérrez et al. (2013) also use our observations to discredit the slumping hypothesis. These empirical findings do not negate the other hypothesis of Finger et al. (2007) that suggests the molluscs were transported by nonabrasive gravity flows (e.g., turbidity currents) of unconsolidated, unstable deposits that had accumulated at the shelf edge. It is also worth noting here that molluscs were typically found in the outcrops as widely scattered individuals with a somewhat chalky surface texture and better preserved in fossil-rich lenses; thus, they did not appear in situ as purported by Gutiérrez et al.

\subsection{Strontium isotope stratigraphy}

To confirm the Early Miocene age of the Navidad Formation, Gutiérrez et al. incorporate some new $\mathrm{Sr}$ dates with those reported by Encinas (2006) but fail to mention those of Nielsen and Glodny (2009). They make no mention of the potential problems with $\mathrm{Sr}$ isotope age-dating that Encinas (2006) discussed, such as those he encountered where Sr dates defy the stratigraphic order of the samples (which is also evident in Figure 3 of Gutiérrez et al.), and where multiple ages derived from the same unit differ by several million years. Both of those situations are particularly evident in the $\mathrm{Sr}$ ages Encinas (2006) obtained from the overlying Licancheu, Rapel and La Cueva formations. Although they mention elsewhere that Encinas (2006) obtained a Sr date of 12.1 \pm 0.7 Ma from a population of the planktic foraminifer that had been identified as Neogloboquadrina acostaensis, it is not considered in their discussion of the $\mathrm{Sr}$ data. Even though that species has a slightly younger first appearance datum, this $\mathrm{Sr}$ date is significantly younger than those derived from the molluscs, which was the main argument used by Encinas (2006) in favor of their reworking. Those specimens are now recognized as members of an Early to early Late Miocene plexus of transitional forms in either the Paragloborotalia nana-Neogloboquadrina continuosa or Paragloborotalia bella-Pg. mayeri lineage, but morphologically skewed toward the two earlier species (Finger, in press).

The aforementioned findings indicate that $\mathrm{Sr}$ ages for the Navidad Formation must be taken with caution, as the original ${ }^{87} \mathrm{Sr} /{ }^{86} \mathrm{Sr}$ ratio can be altered by contamination or recrystallization (e.g., DePaolo, 1986). Such factors could be responsible for any anomalous dates, but most of the $\mathrm{Sr}$ ages obtained from the Navidad Formation are within the Early Miocene interval and are therefore assumed to be reasonably accurate. This is supported by the results of Nielsen and Glodny (2009), who first used scanning electron microscopy (SEM) to recognize and discard diagenetically altered shells; all of their Sr ages fall with the latest Oligocene through Early Miocene interval. 


\subsection{Radiometric dating}

Encinas (2006) obtained Early, late Early to early Middle, and early Late Miocene ${ }^{40} \mathrm{~K} /{ }^{39} \mathrm{Ar}$ and ${ }^{40} \mathrm{Ar} /{ }^{39} \mathrm{Ar}$ ages from scoria and pumice clasts in the Navidad Formation. This inconsistency is not resolved by the two intermediate ${ }^{40} \mathrm{Ar} /{ }^{39} \mathrm{Ar}$ ages $(16.41 \pm 0.45$ and $12.87 \pm 0.5 \mathrm{Ma})$ Gutierrez et al. obtained from pumice clasts.

Encinas (2006) discussed the inconsistency between the older (Early Miocene) radiometric ages and the Late Miocene and Early Pliocene ages indicated by planktic foraminifers and concluded that at least some of the volcanic clasts were probably reworked from older strata. Gutiérrez et al. argue that 'older beds would have been tilted by Andean uplift before the Late Miocene, which upon erosion would have yielded volcanic clasts dispersed throughout the Navidad Formation'. However, Andean uplift also could have occurred during the Late Miocene and progressive unroofing may have exposed different horizons of Early Miocene volcanic rocks. In addition, the Law of Inclusion implies that a clast is always older than the matrix or rock that it is found in. Regardless, we believe the most logical explanation for the presence of distinct pumice-rich intervals is that they represent episodic volcanism contemporaneous with marine deposition. Nevertheless, the radiometric ages cited by Encinas (2006) and Gutiérrez et al. (2013) may be based on isotopic ratios that were slightly altered during transport of the pumice from the Andean Cordillera to the marine basin and therefore must be taken with caution.

\subsection{Ostracodes and pollen}

Gutiérrez et al. (2013) discuss the biostratigraphic value of benthic ostracodes, which were reported in the Navidad Formation by Osorio (1978) and Encinas (2006; species identified by D. Peterson). They note that Bradleya normani has never been reported older than Late Miocene, but do not offer an explanation for its presence in these older strata (e.g., it could reflect upon the paucity of literature on fossil marine ostracodes from the East Pacific margin). Similarly inconclusive is the late Middle Miocene-Late Miocene age that Méon et al. (2004) derived by comparing pollen from the Navidad Formation with the Cenozoic flora of Australia and New Zealand. Despite the long distances that pollen can be transported by winds and ocean gyres, plant communities are highly controlled by their local environment.

\subsection{Planktic foraminifers}

Finger et al. (2007) identified five index species of planktic foraminifers younger than 11.6 Ma. To explain the incongruence with data indicative of Early Miocene ages, Gutiérrez et al. (2013) conclude that those particular species must have appeared much (10-20 Myr) earlier in the Southeast Pacific than elsewhere in the global ocean. We dismiss that hypothesis without hesitation. Modern microfossil biostratigraphy, honed by several decades of deepsea core studies, is based on a voluminous amount of global data that shows regional differences in first appearance datums are considerably narrower and such diachronous events certainly would have been detected by foraminiferal biostratigraphers and paleoceanographers long ago. Hence, the only plausible explanations for the age discrepancy are 1) all of the Early Miocene indications are unreliable, or 2) the planktic foraminifers were misidentified.

We previously considered the ages indicated by planktic foraminifers to be the most reliable (and therefore assumed that the Catapsydrax dissimilis in some assemblages were reworked) for several reasons:

1. The most reliable means of biostratigraphic correlation are microplankton because they are widely distributed by major ocean currents and independent of bottom facies that tend to be geographically time-transgressive and limited. Planktic foraminifers are the marine microfossils that have been most widely utilized for relative age-dating (Haynes, 1981).

2. The identification of index species reported by Finger et al. (2007) were based on illustrations in the primary reference guides on the OligoceneRecent microfauna (Kennett and Srinivasan, 1983; Bolli and Saunders, 1985; Jenkins, 1985), and their identified images were not questioned when shown to several experts.

3. Others who have reported on the Navidad foraminifers, including assemblages from the same localities as ours, indicated the presence of Late Miocene or younger species (e.g., MartínezPardo and Osorio, 1964; Cecioni, 1970; Ibaraki, 1992). 
4. Late Miocene or younger species of planktic foraminifers have also been reported from other marine units in south-central Chile that appear to be coeval with the Navidad Formation (e.g., Marchant and Pineda, 1988; Marchant, 1990; Osorio and Elgueta, 1990).

Despite our previous interpretation, we remained unsettled by all of these Late Miocene interpretations because of their discordancy with other data. This was exacerbated in 2010, when Martin Crundwell, a specialist in Neogene foraminifers at GNS Science in New Zealand, viewed images of our planktic specimens and exclaimed that they were Early or possibly Middle Miocene, based on what he had seen in the classic sections of New Zealand. We subsequently delved into the pertinent literature, particularly the publications of George Scott (NZ Geological Survey), who also provided feedback on the images, which convinced us that some of our identifications, including those of Neogloboquadrina acostaensis and Globorotalia puncticulata, were incorrect. However, neither Crundwell or Scott could assign either form definitively to any other species. It thereupon became clear that many of the planktic foraminifers in the Chilean Miocene could not be specifically ascribed due to their rarity or imperfect preservation, and the absence of continuous stratigraphic sequences that would have added a temporal perspective to their morphologic variability. In light of this revelation and additional microscopic study, we have reassigned all five problematic Navidad species to species, lineages, or groups that characterize the Early Miocene (Finger, in press).

\section{Depositional environment}

Gutiérrez et al. (2013) question our interpretation of the Navidad Formation as a deep-marine deposit, which we derived from our micropaleontologic, sedimentologic, and ichnologic data (Encinas, 2006; Finger et al., 2007; Encinas et al., 2008). They purport that modern upper depth limits of species cannot be applied prior to the Serravallian global cooling event because the thermal stratification of the oceanic water masses would have been markedly different. We consider that view to be merely speculative as it is not based on any evidence. We are aware that extrapolating from the modern fauna to derive paleobathymetric interpretations, like most other paleoecological inferences, has drawbacks, as species are not controlled by water depth but by depth-related environmental parameters that are not geographically or temporally consistent. Although it is now recognized that there are no isobathyal species, it is undeniable that many benthic taxa are typically found only below certain depths. An upper depth limit (UDL) is not definitive - it simply indicates the generalized depth zone above which the species is rarely encountered or abundant. Confidence in the UDL assigned to an assemblage increases with the number of specimens of species that have similar UDLs, and any other data that support it. Our conclusion that the Navidad Formation accumulated well below the shelf break disagrees with the reasoning of Gutiérrez et al. (2013) for the following reasons:

1. Although oceanic stratification accentuated during the late Middle Miocene, cooling of the global ocean occurred in a series of six rapid, step-like transitions that began in the Eocene, and psychrospheric circulation linked to polar glaciation began in the earliest Oligocene (Kennett, 1982). Hence, thermal stratification existed prior to that fifth event, and the bottom water masses along the south-central Chilean margin may not have changed dramatically since the Oligocene. In fact, the late Oligocene extinction of many foraminiferal species, and the Early Miocene appearance of many new ones that are extant support the notion that the modern foraminiferal fauna has changed little since that time. Thus, paleobathymetric interpretations are assumed to be fairly reliable for at least the last $25 \mathrm{Myr}$ (Boltovskoy, 1980).

2. Paleodepth interpretations of fossil assemblages are enhanced by minimal temporal and spatial proximity to the source of the modern data. Many benthic species or their homeomorphs inhabiting the deep waters off south-central Chile occur in the Navidad Formation. It is noteworthy that most of the Neogene benthic foraminifers recovered from ODP Site 1237, drilled at a water depth of $3212 \mathrm{~m}$ off Peru, are taxa identical or similar to those reported from the Navidad by Finger et al. (2007). In addition, nearly half of the 63 provincially extant species that account for $22 \%$ of our Miocene fauna have been provincially recorded only from bathyal depths (Finger, in press).

3. All of our Navidad foraminiferal assemblages have characteristically shallow-water species associated with species that are typically confined 
to deep water. Modern and fossil mixed-depth associations of this sort result from downslope displacement, which is a common phenomenon on the continental slopes of tectonic margins (Ingle, 1980).

4. Some of the Navidad species or their homeomorphs are considered cosmopolitan deep-water species (van Morkhoven et al., 1986; Hayward et al., 2012). Reports of their shallower occurrences off Chile are anomalous.

5. Psychrospheric ostracodes were also recognized in the majority of our assemblages (Finger et al., 2007). They inhabit cold water masses, which usually are at a depth of at least $500 \mathrm{~m}$.

6. The presence of multiple species of foraminifers that are typically restricted to deep-water, in association with psychrospheric ostracodes, is evidence of the ocean stratification that Gutiérrez et al. do not envision at the time of Navidad deposition.

\subsection{Sedimentology}

Gutiérrez et al. indicate that the Navidad Formation represents a shallow coastal to outer shelf environment. They do not show a facies analysis, basing their interpretation on the presence of wave ripple marks in sandstones, delicate insect remains, and the abundance of terrestrial palynomorphs and well-preserved leaves. They propose that sea-level oscillations or tectonic events caused facies belts to migrate laterally and that the upper part of the Navidad Formation was affected by a general rise in sea-level. We disagree with those interpretations based on the following reasons:

1. The Navidad Formation is principally composed of massive sandstones, matrix- and clast- supported conglomerates, interbedded siltstones and sandstones showing Bouma cycles, synsedimentary breccias, slides, slumps, and siltstones (Encinas et al., 2008). Rip-up clasts up to a meter in diameter, water-escape structures, and convolute lamination are common in some of these facies. All of these features are characteristic of gravity flow deposits typical of deep marine environments (Posamentier and Walker, 2006).

2. Some intervals of the Navidad Formation show typical shallow-marine facies (Encinas et al., 2008), and we now question some of our previous interpretations of deep marine environments, such as that for the basal part of the Punta Perro succession where there are some intermittent cross-bedded sandstones, as well as a poorly preserved set of symmetric(?) ripples (Encinas, 2006). However, if all the Navidad Formation had been deposited on the shelf, as proposed by Gutiérrez et al., sedimentary features typical of shallow marine facies (e.g., cross-bedding and hummocky cross-stratification) should be common, which they are not, in the $\sim 40 \mathrm{~km}$ of the unit's well-preserved exposures.

3. Gutiérrez et al. recognize that temporal changes in sedimentary facies can result from sea-level change or tectonics. Wave-dominated or deltaic shallow-marine environments typically show coarsening- and shallowing-upward cycles separated by flooding surfaces (Clifton, 2006). Yet, stratigraphic facies changes in the Navidad Formation are typically abrupt and sometimes delineated by erosive surfaces, load-and flame structures, or flute casts (Encinas, 2006). In many of the studied sections, repetitive facies changes between fine- and coarse-grained facies occur in brief intervals (Encinas, 2006). Abrupt changes in shallow-marine sequences are attributed to forced regressions (Clifton, 2006), but that does not adequately account for the repetitive, abrupt changes observed in a diversity of facies that characterize the Navidad Formation.

4. The occurrence of abundant and well-preserved terrestrial plant debris (leaves, woody fragments, and pollen) is not uncommon in deep-marine turbiditic systems (e.g., Plink-Björklund and Steel, 2004). Such deposits accumulate in deep-marine basins directly offshore from the mouth of a stream (Pineda, 1999; Plink-Björklund and Steel, 2004; Johnson et al., 2001). In fact, some of the most leaf-rich strata (e.g., at Cerro Centinela, Boca Pupuya, and Los Pololos) consist of rhythmically interbedded siltstone and sandstone showing partial Bouma cycles and locally large flames, disrupted siltstone beds, or interbedded slump folds (Encinas, 2006). The Goterones flora, on the other hand, occurs in fine-grained sandstones cross-cut by a submarine channel filled by massive sandstones with large siltstone rip-up clasts and containing abundant planktic foraminifers (Encinas, 2006). In addition, pollen described from the Navidad Formation by Barreda et al. (2011) was mostly derived from siltstones displaying trace fossils 
characteristic of the Zoophycos ichnofacies and yielding abundant planktic foraminifera. All of the aforementioned features are typical of deepmarine turbiditic systems, not tranquil nearshore settings.

5. Granitic boulders (one $\sim 3 \mathrm{~m}$ across) occur in fine-grained strata of the Navidad Formation along the northwestern shore of Punta Perro (Encinas, 2006). The boulders are associated with a synsedimentary breccia composed of large stratified blocks. They occur at the top of a thick siltstone interval that contains abundant planktic foraminifera and shows trace fossils characteristic of the Zoophycos ichnofacies, which characterize deposition on the outer shelf or slope. Large boulders offshore are typically derived from shelf-margin failure commonly triggered by earthquakes, and they are displaced downslope by mass-transport processes (e.g., Festa et al., 2010). It is unlikely that the boulders were derived from the continent and transported to the outer shelf because the shelf gradient is generally $<1^{\circ}$, which minimizes the ability of large clasts to move long distances.

6. The Navidad Formation locally presents large channels (up to $\sim 100 \mathrm{~m}$ wide) with erosive bases that cross-cut underlying strata. They are typically filled with fossiliferous massive sandstones or pebble-to-boulder matrix- and clast-supported conglomerates. These strata normally display ripup siltstone clasts up to $\sim 1$ meter in diameter and thin siltstone intercalations. Submarine channels of this sort are typical of deep-marine turbiditic systems (see Posamentier and Wallker, 2006).

7. Recently, Contardo and Mena (2012) reported the existence of a hydrocarbon paleoseep in strata of the Navidad Formation south of the Estero de Navidad. Its lithologic and isotopic characteristics resemble those of active seeps along the slope of the Chilean margin.

\subsection{Trace fossils}

Gutiérrez et al. (2013) note the presence of Ophiomorpha nodosa, Skolithos linearis, Conichnus conicus, Macaronichnus segregates, and Thalassinoides isp. reported by Encinas (2006) and Encinas et al. (2008) and consider that they represent an upper shoreface environment. They also noted the presence of Diplocraterion parallelum, Lophoctenium isp.,
Zoophycus isp., and Chondrites isp., which Encinas et al. (2008) attributed to a deep-water environment on the continental slope. Gutiérrez et al. consider the two latter trace fossils as not necessarily indicative of water depths much greater than 150-200 $\mathrm{m}$ stating that they may also be present in shallow-marine settings.

Gutiérrez et al. (2013) inaccurately cite some information presented by Encinas (2006) and Encinas et al. (2008). For example, Conichnus conicus and Macaronichnus segregates were found in crossbedded sandstones that were interpreted as shallowmarine facies. However, the Macaronichnus found in massive sandstones at Punta Perro are of dubious identification. In fact, Encinas et al. (2008) cited the presence of two distinct trace fossil associations, one that occurs principally in fine-grained sandstone and siltstone beds and includes Chondrites isp., Zoophycos isp., and rare Lophoctenium isp., Diplocraterion parallelum, and Planolites isp. The other association occurs mostly in massive, medium- to coarse-grained sandstone and principally includes Thalassinoides paradoxicus, Ophiomorpha isp., and rarer Skolithos linearis. We agree that the first association, attributed to the Zoophycos ichnofacies by Encinas et al. (2008), can be also found in outer shelf or even shallower environments. Yet, the latter possibility seems unlikely as they typically occur in siltstones with abundant planktic foraminifers, indicating a environment farther offshore. The second association, attributed to the Skolithos ichnofacies, is indeed typical of shallow marine environments, but it is also common in deepmarine environments where it reflects particular conditions such as high energy (e.g., Buatois and López-Angriman, 1992). Thus, differentiation of depositional paleodepths for the Navidad Formation is difficult if based solely on ichnological studies. Parasequences typical of wave-dominated shallow marine environments show a transition between the Zoophycos, Cruziana, and Skolithos ichnofacies. Many of the Navidad successions show abrupt and locally repetitive changes between fine-grained strata bearing the Zoophycos ichnofacies and coarsergrained beds showing the Skolithos ichnofacies. We consider these features to be more typical of a deep-marine environment where the Zoophycos ichnofacies predominates during calm intervals of low sedimentation, whereas the Skolithos ichnofacies reflects short-term, high-energy conditions associated with the sudden deposition of thick packages of sand (Encinas et al., 2008). 


\section{Stratigraphy of the Navidad Formation}

Gutiérrez et al. propose a subdivision of the Navidad Formation into a lower and an upper unit based on correlation of nine stratigraphic profiles measured in the Punta Perro-Matanzas area. We consider that scheme as too simplistic because: 1 . the upper contact with the Lincancheu Formation (which can be observed near the town of Navidad) is not shown in any of their measured sections; 2 . the Navidad Formation crops out between Punta Toro and Punta Topocalma, a span of $\sim 40 \mathrm{~km}$ (Encinas, 2006; Encinas et al., 2006), and some of the sections located in this region show significant lithological differences when compared with those of the Punta Perro-Matanzas area; 3. correlation of stratigraphic profiles in the area studied by Gutiérrez et al. presents some degree of uncertainty because faults affect the sedimentary successions in this area, whereas the coastal bluffs in the Punta Perro-Matanzas area are widely separated at the mouth of the Estero Navidad. Lithological correlation between these areas is rendered dubious by facies repetition.

\section{Conclusions}

1. Our further study has revised our interpretation to where we agree with Gutiérrez et al. that the age of the Navidad Formation is within the Early to Middle Miocene interval. Although the results from the primary age-dating tools (planktic foraminifers, gastropods, and isotopic ratios) include some discrepancies and assumptions that question their reliability, we are confident that most of our samples can be confined to the late Early Miocene (Burdigalian); the age determinations for the remaining samples were not as restricted, but all ranged into or through that time interval, which prompts us to suggest that all of the Navidad samples are Burdigalian. However, further study is needed to evaluate the few radiometric dates that indicate otherwise in order to confirm the age span of the Navidad Formation.

2. We dismiss the attempt by Gutiérrez et al. to lower the FADs of five planktic foraminifers to explain the age discrepancy that previously existed because doing so is scientifically unsound and we recognize that the problem was created by inaccurate identifications of transitional forms and morphotypic variants that remain in taxonomic limbo.
3. We disagree with the environmental interpretation provided by Gutiérrez et al. Although we do not discard the possibility that the Navidad Formation may have accumulated at depths shallower than lower bathyal, the paleontological and sedimentological evidence favors deposition on the continental slope, not on the shelf. Some parts of the Navidad Formation could have been deposited at shallower depths, but that is not evident in any of our samples.

4. We believe the molluscan assemblages provide for a weak argument against deep-water deposition.

\section{References}

Barreda, V.; Encinas, A.; Hinojosa, L.F. 2011. Polen y esporas de la Formación Navidad, Neógeno de Chile. Revista Chilena de Historia Natural 84: 341-355.

Bolli, H.M.; Saunders, J.B. 1985. Oligocene to Holocene low latitude planktic foraminifera. In Plankton stratigraphy (Bolli, H.M., Saunders, J.B.; Perch-Nielsen, K.; editors). Cambridge University Press, Cambridge Earth Sciences Series: 155-262.

Boltovskoy, E. 1980. On the benthonic bathyal-zone foraminifera as stratigraphic guide fossils. Journal of Foraminiferal Research 10: 163-172.

Buatois, L.; López-Angriman, A. 1992. The ichnology of a submarine braided channel complex: the Whisky Bay Formation, Cretaceous of James Ross Island, Antarctica. Paleogeography, Palaeoclimatology, Palaeoecology 94: 119-140.

Cecioni, G. 1970. Esquema de paleogeografia Chilena. Santiago: Editorial Universitaria: 143 p.

Clifton, H.E. 2006. A reexamination of facies models for clastic shorelines. In Facies models revisited (Posamentier, H.W.; Walker, R.; editors). SEPM Society for Sedimentary Geology, Special Publication 84: 293-338.

Contardo, X.; Mena, E. 2012. Evidencias, caracterización e implicancias del primer seep fósil descubierto en la costa emergida de Chile central. In Congreso Geológico Chileno, No. 13, Actas en CD-Rom, T5: 663-665. Antofagasta.

DePaolo, D.J. 1986. Detailed record of the Neogene Sr isotopic evolution of seawater from DSDP Site 590B. Geology 14: 103-106.

DeVries, T.J.; Frassinetti, D. 2003. Range extensions and biogeographic implications of Chilean Neogene mollusks found in Peru: Museo Nacional de Historia Natural, Chile. Boletín 52: 119-135. 
Encinas, A. 2006. Estratigrafía y sedimentología de los depósitos marinos mio-pleistocénicos del área de Navidad $\left(33^{\circ} 00^{\prime}-34^{\circ} 30^{\prime} \mathrm{S}\right)$, Chile central: Implicaciones con respecto a la tectónica del antearco. Ph.D. dissertation (Unpublished), Universidad de Chile: 177 p. Santiago.

Encinas, A.; Le Roux, J.P.; Buatois, L.A.; Nielsen, S.N.; Finger, K.L.; Fourtanier, E.; Lavenu, A. 2006. Nuevo esquema estratigráfico para los depósitos marinos

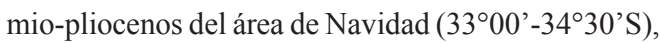
Chile central. Revista Geológica de Chile 33: 221-246.

Encinas, A.; Finger, K.L.; Nielsen, S.N.; Lavenu, A.; Buatois, L.A.; Peterson, D.E.; Le Roux, J.P. 2008. Rapid and major coastal subsidence during the late Miocene in south-central Chile. Journal of South American Earth Sciences 25: 157-175.

Festa, A.; Pini, G.A.; Dilek, Y; Codegone, G. 2010. Mélanges and mélange-forming processes: a historical overview and new concepts. International Geology Review 52: 1040-1105.

Finger, K.L. in press. Miocene foraminifera from the southcentral coast of Chile. Micropaleontology.

Finger, K.L.; Nielsen, S.N.; DeVries, T.J.; Encinas, A.; Peterson, D.E. 2007. Paleontologic evidence of sedimentary displacement in Neogene forearc basins of central Chile. PALAIOS: 3-16.

Gutiérrez, N.; Hinojosa, L.F.; Le Roux, J.P.; Pedroza, V. 2013. Evidence for an early - middle Miocene age of the Navidad Formation (central Chile): paleontological, paleoclimatic and tectonic implications. Andean Geology 40: 66-78.

Haynes, J. 1981. Foraminifera. MacMillan: 433 p. UK.

Hayward B.W.; Kawagata, S.; Sabaa, A.; Grenfell, H.; Van Kerckhoven, L.; Johnson, K.; Thomas, E., 2012. The last global extinction (mid-Pleistocene) of deep-sea benthic foraminifera (Chrysalogoniidae, Ellipsoidinidae, Glandulonodosariidae, Plectofrondiculariidae, Pleurostomellidae, Stilostomellidae), their Late Cretaceous-Cenozoic history and taxonomy. Cushman Foundation for Foraminiferal Research Special Publication 43: 408 p.

Ibaraki, M. 1992. Planktonic foraminifera from the Navidad Formation, Chile: their geologic age and paleoceanographic implications. In Centenary of Japanese Micropaleontology (Ishizaki, K.; Saito, T.; editors). Terra Scientific Publishing Company: 91-95. Tokyo.

Ingle, J.C. Jr. 1980. Cenozoic paleobathymetry and depositional history of selected sequences within the southern California continental borderland. In Studies in marine micropaleontology and paleoecology. A memorial volume to Orville L. Bandy (Sliter, W.V.; editor). Cushman Foundation for Foraminiferal Research, Special Publication 19: 163-195.

Jenkins, D.G. 1985. Southern mid-latitude Paleocene to Holocene planktic foraminifera. In Plankton stratigraphy (Bolli, H.M.; Saunders, J.B.; Perch-Nielsen, K.; editors). Cambridge University Press: 263-282. Cambridge.

Johnson, K.S.; Paull, C.K.; Barry, J.P.; Chávez, F.P. 2001. A decadal record of underflows from a coastal river into the deep sea. Geology 29: 1019-1022.

Kennett, J.P. 1982. Marine Geology. Englewood Cliffs, New Jersey: 813 p. Prentice-Hall.

Kennett, J.P.; Srinivasan, M.S. 1983. Neogene planktonic foraminifera. A phylogenetic atlas. Stroudsburg, Pennsylvania: Hutchinson Ross: 265 p.

Kiel, S.; Nielsen, S.N. 2010. Quaternary origin of the inverse latitudinal diversity gradient among southern Chilean mollusks. Geology 38: 955-958.

Marchant, M. 1990. Foraminíferos Miocénicos de los estratos de Pupunahue (Provincia de Valdivia: X Región): determinación de la edad probable y paleoambiente. In Simposio sobre el Terciario de Chile, No. 2: Procesos y productos de depositación en el ámbito andino, Actas I: 177-188. Concepción.

Marchant, M.; Pineda, V. 1988. Determinación de la edad del miembro superior marino de los estratos de Pupunahue, mediante foraminíferos. In Congreso Geológico Chileno, No. 5, Actas: C311-C325. Santiago.

Martínez-Pardo, R.; Osorio, R. 1964. Discoastéridos y foraminíferos de la Formación Navidad: nuevos antecedentes para su datación. Revista Geológica de Chile 9: 5-6.

Méon, H.; Torres, T.; Martínez-Pardo, R. 1994. Sporopollinic analysis in the Navidad Formation near Navidad (Chile). In Congreso Geológico Chileno, No. 7, Actas: 488-490. Concepción.

Nielsen, S.N.; Glodny, J. 2009. Early Miocene subtropical water temperatures in the southeast Pacific. Palaeogeography, Palaeoclimatology, Palaeoecology 280: 480-488.

Osorio, R. 1978. Ostracoda from the Navidad Formation (Miocene), Chile. Journal of the Faculty of Sciences, Hokkaido University, Series IV, 18: 57-84.

Osorio, R.; Elgueta, S. 1990. Evolucion paleobatimétrica de la cuenca Labranza documentada por foraminiferos. In Simposio sobre el Terciario de Chile, No. 2: 225 233. Concepción.

Pineda, V. 1999. El cañón submarino del Bío-Bío: aspectos dinámicos y ambientales. Ph.D. Thesis (Unpublished), Centro EULA, Universidad de Concepcion: 105 p. 
Plink-Björklund, P.; Steel, R.J. 2004. Initiation of turbidity currents: outcrop evidence for Eocene hyperpycnal flow turbidites. Sedimentary Geology 165: 29-52.

Posamentier, H.W.; Walker, R. 2006. Deep-water turbidites and submarine fans. In Facies models revisited (Posamentier, H.W.; Walker, R.; editors), SEPM Society for Sedimentary Geology, Special Publication 84: 399-520.
Suárez, M.; Encinas, A.; Ward, D. 2006. Early Miocene elasmobranch fauna from the Navidad Formation, central Chile, South America. Cainozoic Research 4: 3-18. van Morkhoven. F.P.C.M.; Berggren, W.A.; Edwards, A.S. 1986. Cenozoic cosmopolitan deep-water benthic foraminifera. Bulletin des Centres de Recherches Exploration-Production Elf-Aquitaine, Mémoire 11: $421 \mathrm{p}$.

$\overline{\text { Manuscript received: June 13, } 2013 .}$ 